\title{
Arcobacter marinus sp. nov.
}

\author{
Hye Min Kim, Chung Yeon Hwang and Byung Cheol Cho
}

Correspondence

Byung Cheol Cho

bccho@snu.ac.kr
School of Earth and Environmental Sciences and Research Institute of Oceanography, Seoul National University, 599 Gwanak-ro, Gwanak-gu, Seoul 151-742, Republic of Korea

A slightly curved, rod-shaped marine bacterium, designated strain $\mathrm{CL}-\mathrm{S} 1^{\top}$, was isolated from near Dokdo, an island in the East Sea, Korea. Cells were Gram-negative and grew well under either aerobic or microaerobic conditions. Analyses of the 16S rRNA and gyrA gene sequences of strain $\mathrm{CL}-\mathrm{S} 1^{\top}$ revealed an affiliation with the genus Arcobacter within the class Epsilonproteobacteria. Phylogenetic analyses based on $16 \mathrm{~S}$ rRNA and gyrA gene sequences showed that strain CL-S1 ${ }^{\top}$ formed a robust clade with Arcobacter halophilus $\mathrm{LA} 1 \mathrm{~B}^{\top}$, with sequence similarities of 96.1 and $88.2 \%$, respectively. DNA-DNA relatedness between strain $\mathrm{CL}-\mathrm{S} 1^{\top}$ and $A$. halophilus DSM $18005^{\top}$ was $44 \%$, indicating that they represent genomically distinct species. Strain $\mathrm{CL}-\mathrm{S} 1^{\top}$ grew optimally at $30-37{ }^{\circ} \mathrm{C}$, at $\mathrm{pH} 7$ and in the presence of $3-5 \% \mathrm{NaCl}$. The dominant cellular fatty acids were iso- $\mathrm{C}_{15: 0} 2-\mathrm{OH}$ and/or $\mathrm{C}_{16: 1} \omega 7 c(28.4 \%), \mathrm{C}_{16: 0}(26.2 \%)$ and $\mathrm{C}_{18: 1} \omega 7 c$ (22.3\%). The DNA G $+\mathrm{C}$ content of strain $\mathrm{CL}-\mathrm{S} 1^{\top}$ was $28 \mathrm{~mol} \%$. Strain $\mathrm{CL}-\mathrm{S} 1^{\top}$ differed phenotypically from $A$. halophilus $\mathrm{LA}_{3} 1 \mathrm{~B}^{\top}$ based on its ability to grow aerobically at $10{ }^{\circ} \mathrm{C}$ and inability to grow under anaerobic conditions. Based on the data presented, strain $\mathrm{CL}-\mathrm{S} 1^{\top}$ is considered to represent a novel species of the genus Arcobacter, for which the name Arcobacter marinus sp. nov. is proposed. The type strain is $\mathrm{CL}-\mathrm{S} 1^{\top}\left(=\mathrm{KCCM} 90072^{\top}=\mathrm{JCM} 15502^{\top}\right)$.
The genus Arcobacter belongs to the family Campylobacteraceae, which also contains the genera Campylobacter and Sulfurospirillum (Vandamme et al., 2005a). The genus Arcobacter was proposed by Vandamme et al. (1991); two Campylobacter species, [Campylobacter] nitrofigilis (McClung et al., 1983) and [Campylobacter] cryaerophilus (Neill et al., 1985), were reclassified as Arcobacter nitrofigilis and Arcobacter cryaerophilus, respectively (Vandamme et al., 1991). [Campylobacter] butzleri (Kiehlbauch et al., 1991) was later reclassified as Arcobacter butzleri (Vandamme et al., 1992). Three other species of the genus (Arcobacter skirrowii, Arcobacter cibarius and Arcobacter halophilus) have been newly described (Vandamme et al., 1992; Houf et al., 2005; Donachie et al., 2005). At the time of writing, the genus thus comprises six recognized species (Donachie et al., 2005; Houf et al., 2005; Vandamme et al., 2005b). Members of the genus Arcobacter have been isolated from various environments. A. cryaerophilus, A. butzleri and A. skirrowii have been recovered from livestock and humans (Neill et al., 1985; Kiehlbauch et al., 1991; Vandamme et al., 1992) and are recognized as potential emerging human pathogens

The GenBank/EMBL/DDBJ accession numbers for the 16S rRNA and gyrA gene sequences of strain CL-S1 ${ }^{\top}$ are EU512920 and FJ754218, respectively.

Neighbour-joining trees based on gyrA gene sequences and inferred amino acid sequences of the gyrA gene and transmission electron micrographs of negatively stained cells of strain $\mathrm{CL}-\mathrm{S} 1^{\top}$ are available as supplementary material with the online version of this paper.
(Mansfield \& Forsythe, 2000). A. nitrofigilis was isolated from Spartina alterniflora roots in a salt marsh (McClung et al., 1983). A. halophilus and A. cibarius were isolated from a hypersaline lagoon (Donachie et al., 2005) and the skin of a broiler carcass (Houf et al., 2005), respectively. In the present study, a novel strain affiliated with the genus Arcobacter was isolated and subjected to a polyphasic taxonomic analysis.

Seaweeds and a starfish were collected and added to a surface seawater sample $(50 \mathrm{ml})$ taken from the vicinity of Dokdo, an island in the East Sea, Korea. The mixture was maintained at $4{ }^{\circ} \mathrm{C}$ for 15 days. The mixture was then homogenized by using a blender and an aliquot $(50 \mu \mathrm{l})$ was spread onto MY medium (Bouchotroch et al., 2001). The culture was incubated aerobically at $30{ }^{\circ} \mathrm{C}$ for 2 weeks. Strain CL-S1 $1^{\mathrm{T}}$ was isolated and subsequently purified on fresh marine agar 2216 (MA; Difco). Strain CL-S1 ${ }^{\mathrm{T}}$ grew well on MA or on saline blood agar [SBA; per litre distilled water: $40 \mathrm{~g}$ blood agar base (BBL), $50 \mathrm{ml}$ sheep blood, $30 \mathrm{~g}$ $\mathrm{NaCl}]$ at $37{ }^{\circ} \mathrm{C}$ under either aerobic or microaerobic conditions. The novel strain was preserved in marine broth 2216 (MB; Difco) supplemented with $30 \%$ (v/v) glycerol at $-80{ }^{\circ} \mathrm{C}$.

For $16 \mathrm{~S}$ rRNA gene amplification by PCR, DNA was extracted from a single colony by a boiling method (Englen \& Kelley, 2000). The crude extracts served as the DNA template for PCRs, which included Taq DNA polymerase (Bioneer) and primers 27F and 1492R (Lane, 1991). The PCR product was purified by using the AccuPrep PCR 
purification kit (Bioneer), and direct sequence determination of the purified $16 \mathrm{~S}$ rRNA gene was performed by using sequencing primers $(27 \mathrm{~F}, 518 \mathrm{~F}, 800 \mathrm{R}$ and $1492 \mathrm{R}$ (Lane, 1991; Anzai et al., 1997) with an Applied Biosystems automated sequencer (ABI3730XL) at Macrogen (Seoul, Korea). For PCR amplification of the gyrA gene (encoding subunit A of DNA gyrase), genomic DNA was extracted from strain CL-S1 ${ }^{\mathrm{T}}$ and A. halophilus DSM $18005^{\mathrm{T}}$ (Donachie et al., 2005) by using the AccuPrep genomic DNA extraction kit. To amplify the gyrA gene, we first employed PCR by using two sets of degenerate primers (Abdelbaqi et al., 2007). However, no PCR product was obtained from the genomic DNA of either strain CL-S1 ${ }^{\mathrm{T}}$ or A. halophilus DSM $18005^{\mathrm{T}}$ in our study (data not shown). We designed new primers based on the alignment of the gyrA gene sequences of recognized Arcobacter strains in GenBank by using the Primer3 program (Rozen \& Skaletsky, 2000). The following primers were used: forward primer, 5'-TGGACGTGCATTACCAGATG-3'; reverse primer, 5'-GCAACTTTTCCTTTTCCACCT-3'. PCR amplifications were performed in a reaction mixture of $20 \mu \mathrm{l}$ (total volume) containing approximately $30 \mathrm{ng}$ genomic DNA, $125 \mu \mathrm{M}$ each dNTP, $0.5 \mu \mathrm{M}$ each primer, $1.5 \mathrm{U}$ Taq DNA polymerase (Bioneer) and the buffer supplied with the enzyme. PCR amplifications were performed according to the following sequence: $95{ }^{\circ} \mathrm{C}(5 \mathrm{~min}), 30$ cycles of $95{ }^{\circ} \mathrm{C}(30 \mathrm{~s})$, annealing at $55^{\circ} \mathrm{C}(30 \mathrm{~s})$ and elongation at $72{ }^{\circ} \mathrm{C}(3 \mathrm{~min})$ and an additional elongation at $72{ }^{\circ} \mathrm{C}$ ( $5 \mathrm{~min}$ ). The PCR product was purified by using the AccuPrep PCR purification kit and was sequenced directly by using the newly designed primers as sequencing primers.

The almost-complete 16S rRNA gene sequence of strain $\mathrm{CL}-S 1^{\mathrm{T}}$ (1426 bp) was obtained along with partial gyrA gene sequences (approximately $60 \%$ coverage) of strain $\mathrm{CL}-S 1^{\mathrm{T}}$ (1410 bp) and A. halophilus DSM $18005^{\mathrm{T}}$ (1368 bp). These sequences were compared with sequences available in GenBank by using the BLASTN algorithm (Altschul et al., 1990). The 16S rRNA gene sequence of strain $\mathrm{CL}-\mathrm{S} 1^{\mathrm{T}}$ was aligned via the jPHYDIT program (Jeon et al., 2005) with sequences of the type strains of recognized Arcobacter species and phylogenetically related taxa obtained from GenBank and the Ribosomal Database Project II database (Cole et al., 2007). Accurate multiple alignment was made manually according to the $16 \mathrm{~S}$ rRNA gene secondary-structure information implemented in the jPHYDIT program. For the gyrA gene sequences of strain CL$\mathrm{S1}^{\mathrm{T}}$, A. halophilus DSM $18005^{\mathrm{T}}$, other type strains of recognized Arcobacter species and phylogenetically related taxa obtained from GenBank, multiple sequence alignment was performed by using the T-COFFEE program (Notredame et al., 2000). Phylogenetic trees were obtained according to the neighbour-joining (Saitou \& Nei, 1987), maximumparsimony (Fitch, 1971) and maximum-likelihood (Felsenstein, 1981) methods. An evolutionary distance matrix for the neighbour-joining method was generated according to the model of Jukes \& Cantor (1969). The robustness of tree topologies was assessed by bootstrap analyses, with 1000 replications for the neighbour-joining and maximum-parsimony methods and 100 replications for the maximum-likelihood method. Phylogenetic analyses were carried out by using MEGA 3 (Kumar et al., 2004) and PAUP 4.0 (Swofford, 1998). Likelihood parameters were estimated by using the hierarchical ratio tests in MODELTEST version 3.04 (Posada \& Crandall, 1998). Levels of genomic DNA relatedness between strains CL-S1 ${ }^{\mathrm{T}}$ and A. halophilus DSM $18005^{\mathrm{T}}$ were determined by dot-blot hybridization as described by Choi et al. (2006). The experiment was repeated on different days.

Morphological, physiological and biochemical analyses were performed in duplicate. A. halophilus DSM $18005^{\mathrm{T}}$ was used as a reference strain for all tests. Unless specified otherwise, phenotypic characteristics of strains CL-S1 ${ }^{\mathrm{T}}$ and A. halophilus DSM $18005^{\mathrm{T}}$ were based on cultures grown on SBA at $37{ }^{\circ} \mathrm{C}$ under both aerobic and microaerobic conditions. Gram-staining was performed as described by Smibert \& Krieg (1994). Cell shape and size and presence of flagella were determined by using transmission electron microscopy (EX2; JEOL) with cells grown under both aerobic and microaerobic conditions for 1 and 7 days. Cell motility was observed by phase-contrast microscopy (BX50; Olympus). Anaerobic and microaerobic growth were checked on SBA, MA and trypticase soy agar (TSA; Difco) supplemented with $3 \% \mathrm{NaCl}$; growth was tested by using GasPak Anaerobe and GasPak Campy Container systems (BBL) at $37{ }^{\circ} \mathrm{C}$ for 15 days. Anaerobic growth was further tested on a synthetic growth agar (Teske et al., 1996 ) in the presence of $10 \% \mathrm{CO}_{2}$ and $90 \% \mathrm{~N}_{2}$ at $35{ }^{\circ} \mathrm{C}$ for 15 days. The temperature range for growth was assessed based on colony formation on SBA incubated aerobically at $5-40{ }^{\circ} \mathrm{C}$ (increments of $5{ }^{\circ} \mathrm{C}$ ) and at $37{ }^{\circ} \mathrm{C}$. The tolerance of strain $\mathrm{CL}-\mathrm{S} 1^{\mathrm{T}}$ to $\mathrm{NaCl}$ was determined based on the formation of visible single colonies on TSA with different concentrations of $\mathrm{NaCl}(1-15 \%$ in increments of $1 \%$ as well as $0.5,1.5,2.5$ and $3.5 \%, \mathrm{w} / \mathrm{v})$ at $37{ }^{\circ} \mathrm{C}$ aerobically. The $\mathrm{pH}$ range $(\mathrm{pH} 4.0,4.5,5.0,5.9,7.0,7.5,8.0,8.5,9.4$ and 10.3) for growth in $\mathrm{MB}$ was determined by assessing changes in $\mathrm{OD}_{600}$ over an incubation period of 6 days at $37^{\circ} \mathrm{C}$; prior to autoclaving the medium, its $\mathrm{pH}$ was adjusted by using $1 \mathrm{M} \mathrm{NaOH}$ and $1 \mathrm{M} \mathrm{HCl}$ solutions. After autoclaving and cooling, the $\mathrm{pH}$ in the test medium increased by $0.1-0.4 \mathrm{pH}$ units (for $\mathrm{pH} 4.0-8.0$ and 9.4) or decreased by $0.7 \mathrm{pH}$ units (for $\mathrm{pH} 10.3$ ). Thus, the $\mathrm{pH}$ was measured in subsamples of each medium, before inoculation with bacterial cells.

Catalase and oxidase tests were performed according to the protocols described by Smibert \& Krieg (1994). Hydrolysis of urea was determined as described by Owen et al. (1985). Nitrate reductase activity was determined according to Hansen \& Sørheim (1991). $\mathrm{H}_{2} \mathrm{~S}$ production and hydrolysis of hippurate were determined as described by Skirrow \& Benjamin (1980). Hydrolysis of indoxyl acetate was determined according to Popovic-Uroic et al. (1990). Alkaline phosphatase activity was determined as described by Reddy et al. (2007). 
Fatty acid methyl esters in whole cells of strain CL-S1 ${ }^{\mathrm{T}}$ grown on SBA at $37{ }^{\circ} \mathrm{C}$ microaerobically for 1 day were analysed by GC according to the instructions of the Microbial Identification System (MIDI) at the Korean Culture Center of Microorganisms (KCCM; Seoul, Korea). The DNA G $+\mathrm{C}$ content was determined by HPLC (HP 100; Hewlett Packard) of deoxyribonucleosides as described by Mesbah et al. (1989), after DNA extraction had been performed according to the method proposed by Marmur (1961). Lambda phage DNA was used as a standard, and genomic DNA of A. halophilus DSM $18005^{\mathrm{T}}$ (35 mol\%; Donachie et al., 2005) and Pseudomonas jinjuensis KACC $10760^{\mathrm{T}}$ (66.9 mol\%; Kwon et al., 2003) was used as references.

Phylogenetic analyses based on 16S rRNA gene sequences revealed that strain $\mathrm{CL}-\mathrm{S1}^{\mathrm{T}}$ fell within the cluster comprising Arcobacter species (Fig. 1). The closest relative of strain CL-S1 ${ }^{\mathrm{T}}$ was A. halophilus $\mathrm{LA} 31 \mathrm{~B}^{\mathrm{T}}(96.1 \% 16 \mathrm{~S}$ rRNA gene sequence similarity). Levels of $16 \mathrm{~S}$ rRNA gene sequence similarity between strain $\mathrm{CL}-\mathrm{S} 1^{\mathrm{T}}$ and the type strains of other Arcobacter species were 92.4-94.3\%. In phylogenetic trees constructed with the three algorithms, strain $\mathrm{CL}-\mathrm{S} 1^{\mathrm{T}}$ formed a tight clade with $A$. halophilus $\mathrm{LA} 1 \mathrm{~B}^{\mathrm{T}}$ (Fig. 1), showing high bootstrap values (neighbour-joining, 99\%; maximum-likelihood, $85 \%$; maximum-parsimony, $93 \%$ ). Phylogenetic analyses based on gyrA gene sequences gave results similar to those based on 16S rRNA gene sequences (Supplementary Fig. S1a available in IJSEM Online). Strain CL-S1 ${ }^{\mathrm{T}}$ was affiliated with the genus Arcobacter and was related most closely to the type strain of $A$. halophilus ( $88.3 \%$ gyrA gene sequence similarity) followed by other members of the genus Arcobacter (81.2-84.0\% gyrA gene sequence similarity). The level of gyrA gene sequence divergence between the type strain of A. halophilus and strain CL-S1 ${ }^{\mathrm{T}}(11.7 \%)$ was similar to the range of sequence divergences between the six recognized Arcobacter species (10.2-18.6\%; Supplementary Fig. S1a). The level of DNA-DNA relatedness between strain CL-S1 ${ }^{\mathrm{T}}$ and A. halophilus DSM $18005^{\mathrm{T}}$ was $44 \%$, indicating that they represent genomically distinct species. Taken together, the above results indicate that strain CL-S1 ${ }^{\mathrm{T}}$ represents a novel species of the genus Arcobacter.

Cells of strain CL-S1 ${ }^{\mathrm{T}}$ were Gram-negative and motile with a single polar flagellum (Supplementary Fig. S2a). Cells were slightly curved rods (Supplementary Fig. S2b) in cultures grown for 1 and 7 days. Cell shape and size did not differ between cells grown under aerobic or microaerobic conditions. All phenotypic tests with cells of strain CL-S1 ${ }^{\mathrm{T}}$ grown under microaerobic conditions gave results consistent with those grown under aerobic conditions except hydrolysis of indoxyl acetate. Indoxyl acetate was hydrolysed by cells grown under microaerobic conditions, but not by those grown under aerobic conditions. Other phenotypic characteristics of strain $\mathrm{CL}-\mathrm{S} 1^{\mathrm{T}}$ are given in the species description below and in Table 1 . The fatty acid profile of strain CL-S1 ${ }^{\mathrm{T}}$ is given in Table 2.

Several chemotaxonomic and phenotypic characteristics could be used to differentiate strain $\mathrm{CL}-\mathrm{S1}^{\mathrm{T}}$ from recognized Arcobacter species. The inability to grow under anaerobic conditions differentiated strain CL-S1 ${ }^{\mathrm{T}}$ from $A$. nitrofigilis, A. skirrowii, A. cibarius and A. halophilus (Table 1). Strain $\mathrm{CL}-\mathrm{S1}^{\mathrm{T}}$ could be distinguished from its phylogenetically closest relative, A. halophilus, by its ability to grow at $10{ }^{\circ} \mathrm{C}$ aerobically (this test was performed simultaneously for strain CL-S1 ${ }^{\mathrm{T}}$ and A. halophilus DSM $18005^{\mathrm{T}}$ in this study; not shown). Strain CL-S1 ${ }^{\mathrm{T}}$ could be distinguished from $A$. nitrofigilis by its inability to produce catalase (Table 1) and from A. butzleri by the absence of $\mathrm{C}_{16: 1} \omega 7 t$ and $\mathrm{C}_{14: 1} \omega 6 c$ (Table 2). Strain CL-S1 ${ }^{\mathrm{T}}$ could be distinguished from A. skirrowii by the absence of $\mathrm{C}_{16: 1} \omega 7$ (Table 2) and its inability to produce catalase and haemolysis (Table 1). Strain CL-S1 ${ }^{\mathrm{T}}$ could be distinguished from $A$. cibarius by its ability to produce nitrate reductase and ability to grow in air at $37^{\circ} \mathrm{C}$ and in the presence of $2-4 \% \mathrm{NaCl}$ (Table 1). Strain CL-S1 ${ }^{\mathrm{T}}$ could be distinguished from $A$. cryaerophilus by the absence of $\mathrm{C}_{14: 1} \omega 6 \mathrm{c}$ (Table 2) and its ability to grow in the presence of $4 \%$ $\mathrm{NaCl}$ (Table 1).

In conclusion, the phylogenetic, chemotaxonomic and phenotypic data obtained in this study indicate that strain

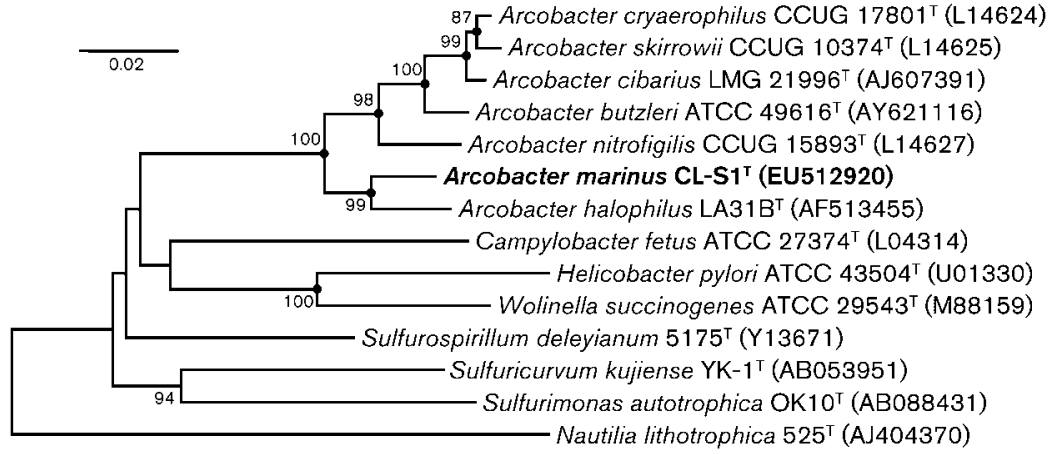

Fig. 1. Neighbour-joining tree based on $16 \mathrm{~S}$ rRNA gene sequences showing the relationship between strain $\mathrm{CL}-\mathrm{S} 1^{\top}$ and members of the genus Arcobacter. Bootstrap values (expressed as percentages of 1000 replications) $>80 \%$ are shown at nodes. Solid circles indicate that the corresponding nodes were also recovered in trees generated with the maximum-likelihood and maximum-parsimony methods. The sequence of Nautilia lithotrophica $525^{\top}$ was used as an outgroup. Bar, 0.02 nucleotide substitutions per site. 
Table 1. Differential characteristics between strain $\mathrm{CL}-\mathrm{S} 1^{\top}$ and recognized Arcobacter species

Taxa: 1, strain CL-S1 ${ }^{\mathrm{T}}$; 2, A. halophilus (data from Donachie et al., 2005); 3, A. nitrofigilis; 4, A. butzleri; 5, A. skirrowii; 6, A. cibarius (Houf et al., 2005); 7, A. cryaerophilus. For taxa 3-5 and 7, phenotypic data and DNA G +C content data were from Vandamme et al. (1992) and Vandamme et al. (2005b), respectively. Prior to phenotypic tests, cells were grown under microaerobic conditions at $37{ }^{\circ} \mathrm{C}$ for taxa $1,3-5$ and 7 , and at $18-22{ }^{\circ} \mathrm{C}$ for taxon 2 (temperature data were not available for taxon 6; Houf et al., 2005). Unless indicated otherwise, all phenotypic tests were performed under microaerobic conditions at $37^{\circ} \mathrm{C}$. All strains were positive for oxidase and hydrolysis of indoxyl acetate. All strains were negative for Gram staining, $\mathrm{H}_{2} \mathrm{~S}$ production, hydrolysis of hippurate and alkaline phosphatase. +, Positive; -, negative; $\mathrm{v}$, variable; w, weakly positive.

\begin{tabular}{|c|c|c|c|c|c|c|c|}
\hline Characteristic & 1 & 2 & 3 & 4 & 5 & 6 & 7 \\
\hline Anaerobic growth & - & + & + & $+/ \mathrm{V}^{*}$ & + & $\mathrm{w}$ & $+/ \mathrm{v}^{*}$ \\
\hline Catalase & - & $-\dagger$ & + & $+/ \mathrm{V}^{*}$ & + & $\mathrm{v} \dagger$ & $+/ \mathrm{v}^{*}$ \\
\hline Urease & - & $-\dagger$ & $-1+\hbar$ & - & - & $-\dagger$ & - \\
\hline Nitrate reductase & + & $+\dagger$ & + & $+/ \mathrm{V}^{*}$ & + & $-\dagger$ & $\mathrm{V}$ \\
\hline Haemolysis & - & $-\dagger$ & - & $\mathrm{V}$ & + & $-\dagger$ & $-/ \mathrm{v}^{*}$ \\
\hline \multicolumn{8}{|l|}{ Growth in: } \\
\hline Air at $37^{\circ} \mathrm{C}$ & + & + & $\mathrm{V}$ & + & + & - & $\mathrm{V}$ \\
\hline $2 \%(\mathrm{w} / \mathrm{v}) \mathrm{NaCl}$ & + & $+\dagger$ & $+\ddagger$ & $+^{*}$ & $+^{*}$ & $-\dagger$ & $\mathrm{V}^{*}$ \\
\hline $4 \%(\mathrm{w} / \mathrm{v}) \mathrm{NaCl}$ & + & $+\dagger$ & $+\ddagger$ & $\mathrm{V}^{\star}$ & $+^{*}$ & $-\dagger$ & $-*$ \\
\hline DNA G $+C$ content $(\mathrm{mol} \%)$ & 28 & 35 & $28-29$ & $28-31$ & $29-30$ & $26.8-27.3$ & $28-30$ \\
\hline
\end{tabular}

${ }^{\star}$ Temperature for cultivation of cells was not available (Atabay et al., 1998); for the anaerobic growth test, a temperature of $25{ }^{\circ} \mathrm{C}$ was used for taxon 4 (Atabay et al., 1998) and, for taxon 7, the result was from On et al. (1996).

$\uparrow$ Temperature for the tests was not available.

$¥$ Temperature for both cultivation of cells and performing the tests was $25^{\circ} \mathrm{C}$ (On et al., 1996).

$\mathrm{CL}-\mathrm{S} 1^{\mathrm{T}}$ represents a novel species of the genus Arcobacter, for which we propose the name Arcobacter marinus sp. nov.

\section{Description of Arcobacter marinus sp. nov.}

Arcobacter marinus (ma.ri'nus. L. masc. adj. marinus referring to the sea, from where the type strain was isolated).
Cells grow well under both aerobic and microaerobic conditions. Cells are slightly curved rods, approximately $0.5-1.7 \mu \mathrm{m}$ long and $0.1-0.3 \mu \mathrm{m}$ wide. Cells are Gramnegative and motile with a single polar flagellum. After 3 days on MA plates at $37^{\circ} \mathrm{C}$, colonies are circular, convex, creamy white and approximately $1 \mathrm{~mm}$ in diameter. After 3 days on SBA plates at $37^{\circ} \mathrm{C}$, colonies are irregular,

Table 2. Cellular fatty acid composition of strain $\mathrm{CL}-\mathrm{S} 1^{\top}$ and recognized Arcobacter species

Taxa: 1, strain CL-S1 ${ }^{\mathrm{T}}$; 2, A. halophilus; 3, A. nitrofigilis; 4, A. butzleri; 5, A. skirrowii; 6, A. cryaerophilus. Data for taxa 2 and 3-6 are from Donachie et al. (2005) and Vandamme et al. (1992), respectively. All strains were cultivated at $37{ }^{\circ} \mathrm{C}$ on blood agar supplemented with $0.5 \% \mathrm{NaCl}$ (final concentration) except strains CL-S1 ${ }^{\mathrm{T}}$ and A. halophilus $\mathrm{LA}_{31 \mathrm{~B}}{ }^{\mathrm{T}}$, for which blood agar supplemented with $3.5 \% \mathrm{NaCl}$ (final concentration) was used. Values are percentage of total fatty acids. ND, Not detected or $<1 \%$. Data are not available for A. cibarius.

\begin{tabular}{|c|c|c|c|c|c|c|}
\hline Fatty acid & 1 & 2 & 3 & 4 & 5 & 6 \\
\hline$C_{12: 0}$ & 6.6 & 8.2 & 7.2 & 6.8 & 9.1 & $3.7-7.7$ \\
\hline $\mathrm{C}_{14: 0}$ & 5.0 & 5.0 & 4.8 & 3.2 & 2.4 & $1.7-1.8$ \\
\hline$C_{16: 0}$ & 26.2 & 19.3 & 32.0 & 19.6 & 22.2 & $17.8-18.7$ \\
\hline $\mathrm{C}_{18: 0}$ & 1.6 & $\mathrm{ND}$ & ND & $\mathrm{ND}$ & $\mathrm{ND}$ & $\mathrm{ND}$ \\
\hline $\mathrm{C}_{14: 1} \omega 6 c$ & $\mathrm{ND}$ & $\mathrm{ND}$ & $\mathrm{ND}$ & 4.9 & 1.4 & 9.2 \\
\hline $\mathrm{C}_{16: 1} \omega 7 c$ & $28.4^{\star}$ & 37.9 & 30.9 & 19.2 & 22.8 & $19.0-45.2$ \\
\hline $\mathrm{C}_{16: 1} \omega 6 t$ & $\mathrm{ND}$ & $\mathrm{ND}$ & $\mathrm{ND}$ & 13.8 & 7.8 & ND-18.8 \\
\hline $\mathrm{C}_{18: 1} \omega 9 c$ & 2.1 & $\mathrm{ND}$ & $\mathrm{ND}$ & $\mathrm{ND}$ & $\mathrm{ND}$ & $\mathrm{ND}$ \\
\hline $\mathrm{C}_{18: 1} \omega 7 c$ & 22.3 & 21.7 & 12.8 & 11.6 & 19.7 & $10.6-10.8$ \\
\hline $\mathrm{C}_{12: 0} 3-\mathrm{OH}$ & 2.9 & 2.7 & 5.5 & $\mathrm{ND}$ & $\mathrm{ND}$ & $\mathrm{ND}$ \\
\hline iso- $\mathrm{C}_{16: 1} \mathrm{I}, \mathrm{C}_{14: 0} 3-\mathrm{OH}$ and/or $\mathrm{C}_{12: 0}$ alde & 2.0 & 2.1 & $5.3 \dagger$ & $17.4 \dagger$ & $9.2 \dagger$ & $9.4-14.3 \dagger$ \\
\hline
\end{tabular}

${ }^{*}$ Reported as summed feature 3 (iso- $\mathrm{C}_{15: 0} 2-\mathrm{OH}$ and/or $\mathrm{C}_{16: 1} \omega 7 \mathrm{c}$ ).

$\dagger$ Reported as $\mathrm{C}_{14: 0}$ 3-OH (Vandamme et al., 1992). 
umbonate, grey and approximately $4 \mathrm{~mm}$ in diameter. Growth occurs at $10-40{ }^{\circ} \mathrm{C}$ (optimum $30-37{ }^{\circ} \mathrm{C}$ ) and at $\mathrm{pH}$ 5.9-8.5 (optimum $\mathrm{pH} 7.0$ ). Growth occurs at $\mathrm{NaCl}$ concentrations of $1-9 \%(\mathrm{w} / \mathrm{v})$ (optimum 3-5\%). Oxidase is produced, but catalase, urease, alkaline phosphatase and $\mathrm{H}_{2} \mathrm{~S}$ are not. Nitrate is reduced. Indoxyl acetate is hydrolysed but hippurate is not. Haemolysis is not observed. The dominant fatty acids are iso- $\mathrm{C}_{15: 0} 2-\mathrm{OH}$ and/or $\mathrm{C}_{16: 1} \omega 7 c, \mathrm{C}_{16: 0}$ and $\mathrm{C}_{18: 1} \omega 7 c$. The DNA G+C content of the type strain is $28 \mathrm{~mol} \%$.

The type strain, CL-S1 ${ }^{\mathrm{T}}\left(=\mathrm{KCCM} 90072^{\mathrm{T}}=\mathrm{JCM} 15502^{\mathrm{T}}\right)$, was isolated from seawater to which seaweeds and a starfish were added.

\section{Acknowledgements}

We acknowledge the expert technical support of Ms In-Sung Lee (electron microscopy) of the National Center for Inter-university Research Facilities at Seoul National University. This work was supported by the BK21 project of the Korean Government and 'A Sustainable Research and Development of the Dokdo (PM46400)' project.

\section{References}

Abdelbaqi, K., Ménard, A., Prouzet-Mauleon, V., Bringaud, F., Lehours, P. \& Mégraud, F. (2007). Nucleotide sequence of the gyrA gene of Arcobacter species and characterization of human ciprofloxacin-resistant clinical isolates. FEMS Immunol Med Microbiol 49, 337345.

Altschul, S. F., Gish, W., Miller, W., Myers, E. W. \& Lipman, D. J. (1990). Basic local alignment search tool. J Mol Biol 215, 403-410.

Anzai, Y., Kudo, Y. \& Oyaizu, H. (1997). The phylogeny of the genera Chryseomonas, Flavimonas, and Pseudomonas supports synonymy of these three genera. Int J Syst Bacteriol 47, 249-251.

Atabay, H. I., Corry, J. E. L. \& On, S. L. W. (1998). Diversity and prevalence of Arcobacter spp. in broiler chickens. J Appl Microbiol 84, 1007-1016.

Bouchotroch, S., Quesada, E., del Moral, A., Llamas, I. \& Béjar, V. (2001). Halomonas maura sp. nov., a novel moderately halophilic, exopolysaccharide-producing bacterium. Int J Syst Evol Microbiol 51, 1625-1632.

Choi, D. H., Kim, Y.-G., Hwang, C. Y., Yi, H., Chun, J. \& Cho, B. C. (2006). Tenacibaculum litoreum sp. nov., isolated from tidal flat sediment. Int J Syst Evol Microbiol 56, 635-640.

Cole, J. R., Chai, B., Farris, R. J., Wang, Q., Kulam-Syed-Mohideen, A. S., McGarrell, D. M., Bandela, A. M., Cardenas, E., Garrity, G. M. \& other authors (2007). The ribosomal database project (RDP-II): introducing $m y \mathrm{RDP}$ space and quality controlled public data. Nucleic Acids Res 35, D169-D172.

Donachie, S. P., Bowman, J. P., On, S. L. W. \& Alam, M. (2005). Arcobacter halophilus sp. nov., the first obligate halophile in the genus Arcobacter. Int J Syst Evol Microbiol 55, 1271-1277.

Englen, M. D. \& Kelley, L. C. (2000). A rapid DNA isolation procedure for the identification of Campylobacter jejuni by the polymerase chain reaction. Lett Appl Microbiol 31, 421-426.

Felsenstein, J. (1981). Evolutionary trees from DNA sequences: a maximum likelihood approach. J Mol Evol 17, 368-376.
Fitch, W. M. (1971). Toward defining the course of evolution: minimum change for a specific tree topology. Syst Zool 20, 406-416.

Hansen, G. H. \& Sørheim, R. (1991). Improved method for phenotypical characterization of marine bacteria. J Microbiol Methods 13, 231-241.

Houf, K., On, S. L. W., Coenye, T., Mast, J., Hoof, J. V. \& Vandamme, P. (2005). Arcobacter cibarius sp. nov., isolated from broiler carcasses. Int J Syst Evol Microbiol 55, 713-717.

Jeon, Y.-S., Chung, H., Park, S., Hur, I., Lee, J.-H. \& Chun, J. (2005). jPHYDIT: a JAVA-based integrated environment for molecular phylogeny of ribosomal RNA sequences. Bioinformatics 21, 31713173.

Jukes, T. H. \& Cantor, C. R. (1969). Evolution of protein molecules. In Mammalian Protein Metabolism, vol. 3, pp. 21-132. Edited by H. N. Munro. New York: Academic Press.

Kiehlbauch, J. A., Brenner, D. J., Nicholson, M. A., Baker, C. N., Patton, C. M., Steigerwalt, A. G. \& Wachsmuth, I. K. (1991). Campylobacter butzleri sp. nov. isolated from humans and animals with diarrheal illness. J Clin Microbiol 29, 376-385.

Kumar, S., Tamura, K. \& Nei, M. (2004). MEGA 3: integrated software for molecular evolutionary genetics analysis and sequence alignment. Brief Bioinform 5, 150-163.

Kwon, S. W., Kim, J. S., Park, I. C., Yoon, S. H., Park, D. H., Lim, C. K. \& Go, S. J. (2003). Pseudomonas koreensis sp. nov., Pseudomonas umsongensis sp. nov. and Pseudomonas jinjuensis sp. nov., novel species from farm soils in Korea. Int J Syst Evol Microbiol 53, 21-27.

Lane, D. J. (1991). 16S/23S rRNA sequencing. In Nucleic Acid Techniques in Bacterial Systematics, pp. 115-175. Edited by E. Stackebrandt \& M. Goodfellow. Chichester: Wiley.

Mansfield, L. P. \& Forsythe, S. J. (2000). Arcobacter butzleri, A. skirrowii and A. cryaerophilus - potential emerging human pathogens. Rev Med Microbiol 11, 161-170.

Marmur, J. (1961). A procedure for the isolation of deoxyribonucleic acid from microorganisms. J Mol Biol 3, 208-218.

McClung, C. R., Patriquin, D. G. \& Davis, R. E. (1983). Campylobacter nitrofigilis sp. nov., a nitrogen-fixing bacterium associated with roots of Spartina alterniflora. Int J Syst Bacteriol 33, 605-612.

Mesbah, M., Premachandran, U. \& Whitman, W. B. (1989). Precise measurement of the $\mathrm{G}+\mathrm{C}$ content of deoxyribonucleic acid by highperformance liquid chromatography. Int J Syst Bacteriol 39, 159-167.

Neill, S. D., Campbell, J. N., O’Brien, J. J., Weatherup, S. T. C. \& Ellis, W. A. (1985). Taxonomic position of Campylobacter cryaerophila sp. nov. Int J Syst Bacteriol 35, 342-356.

Notredame, C., Higgins, D. G. \& Heringa, J. (2000). T-Coffee: a novel method for fast and accurate multiple sequence alignment. J Mol Biol 302, 205-217.

On, S. L. W., Holmes, B. \& Sackin, M. J. (1996). A probability matrix for the identification of campylobacters, helicobacters and allied taxa. J Appl Bacteriol 81, 425-432.

Owen, R. J., Martin, S. R. \& Borman, P. (1985). Rapid urea hydrolysis by gastric campylobacters. Lancet $\mathbf{1}, 111$.

Popovic-Uroic, T., Patton, C. M., Nicholson, M. A. \& Kiehlbauch, J. A. (1990). Evaluation of the indoxyl acetate hydrolysis test for rapid differentiation of Campylobacter, Helicobacter, and Wolinella species. J Clin Microbiol 28, 2335-2339.

Posada, D. \& Crandall, K. A. (1998). MODELTEST: testing the model of DNA substitution. Bioinformatics 14, 817-818.

Reddy, C. A., Beveridge, T. J., Brenznak, J. A., Marzluf, G. A., Schmidt, T. M. \& Snyder, L. R. (2007). In Methods for General and Molecular Microbiology, 3rd edn, section VI, p. 957. Washington, DC: American Society for Microbiology. 
Rozen, S. \& Skaletsky, H. (2000). Primer3 on the WWW for general users and for biologist programmers. In Bioinformatics Methods and Protocols: Methods in Molecular Biology, pp. 365-386. Edited by S. Krawetz \& S. Misener. Totowa, NJ: Humana Press.

Saitou, N. \& Nei, M. (1987). The neighbor-joining method: a new method for reconstructing phylogenetic trees. Mol Biol Evol 4, 406425.

Skirrow, M. B. \& Benjamin, J. (1980). Differentiation of enteropathogenic Campylobacter. J Clin Pathol 33, 1122.

Smibert, R. M. \& Krieg, N. R. (1994). Phenotypic characterization. In Methods for General and Molecular Bacteriology, pp. 607-654. Edited by P. Gerhardt, R. G. E. Murray, W. A. Wood \& N. R. Krieg. Washington, DC: American Society for Microbiology.

Swofford, D. L. (2002). PAUP ${ }^{*}$ : Phylogenetic analysis using parsimony (and other methods), version 4. Sunderland, MA: Sinauer Associates.

Teske, A., Sigalevich, P., Cohen, Y. \& Muyzer, G. (1996). Molecular identification of bacteria from a coculture by denaturing gradient gel electrophoresis of $16 \mathrm{~S}$ ribosomal DNA fragments as a tool for isolation in pure cultures. Appl Environ Microbiol 62, 42104215 .
Vandamme, P., Falsen, E., Rossau, R., Hoste, B., Segers, P., Tytgat, R. \& De Ley, J. (1991). Revision of Campylobacter, Helicobacter, and Wolinella taxonomy: emendation of generic descriptions and proposal of Arcobacter gen. nov. Int J Syst Bacteriol 41, 88-103.

Vandamme, P., Vancanneyt, M., Pot, B., Mels, L., Hoste, B., Dewettinck, D., Vlaes, L., Van Den Borre, C., Higgins, R. \& other authors (1992). Polyphasic taxonomic study of the emended genus Arcobacter with Arcobacter butzleri comb. nov. and Arcobacter skirrowii sp. nov., an aerotolerant bacterium isolated from veterinary specimens. Int J Syst Bacteriol 42, 344-356.

Vandamme, P., Dewhirst, F. E., Paster, B. J. \& On, S. L. W. (2005a). Family I. Campylobacteraceae Vandamme and De Ley $1991,453^{\mathrm{VP}}$. In Bergey's Manual of Systematic Bacteriology, 2nd edn, vol. 2, part C, pp. 1145-1146. Edited by D. J. Brenner, N. R. Krieg, J. T. Staley \& G. M. Garrity. New York: Springer.

Vandamme, P., Dewhirst, F. E., Paster, B. J. \& On, S. L. W. (2005b). Genus II. Arcobacter Vandamme, Falsen, Rossau, Hoste, Segers, Tytgat and De Ley 1991a, 99 ${ }^{\mathrm{VP}}$ emend. Vandamme, Falsen, Rossau, Hoste, Dewettinck, Vlaes, Van Den Borre, Higgins, Hommez, Kersters, Butzler and Goossens 1992b, 355. In Bergey's Manual of Systematic Bacteriology, 2nd edn, vol. 2, part C, pp. 1161-1165. Edited by D. J. Brenner, N. R. Krieg, J. T. Staley \& G. M. Garrity. New York: Springer. 